UDC 004.942:629.023

I. Sydorenko, DSc, Prof.,

V. Salii,

S. Kovban,

M. Kuzmych,

Hailong Jiang

Odessa Polytechnic State University, 1 Shevchenko Ave., Odessa, Ukraine, 65044; e-mail: igs.ods@gmal.com

\title{
HUMAN BODY CAD MODELING IN THE FORM OF A VARIABLE DENSITY OBJECT
}

\begin{abstract}
I.I. Сидоренко. B.I. Салій, С.В. Ковбан, М.В. Кузмич, Хайлун Цзян. Моделювання тіла людини в САПР у вигляді об'єкта змінної щільності. Високі темпи технологічного прогресу сприяють розвитку і вдосконаленню усіх сфер діяльності людини, включаючи біомеханічні дослідження. Розробка нових протезів, ортезів і екзоскелетів пред’являють підвищені вимоги до визначення мас-інерційних характеристик людського тіла. В роботі проаналізовано існуючі експериментально-аналітичні та аналітичні методики визначення центру ваги тіла людини, які засновані на методі сегментації. Показано, що існуючі аналітичні методи не надають повну інформацію про індивідуальні особливості об'єкта, що моделюється, при його реалізації засобами САПР, а дають лише узагальнені результати без урахування фізичного розвитку, стану здоров'я та інших індивідуальних особливостей людини. В роботі запропоновано удосконалення аналітичної методики, що дозволяє підвищити точність визначення мас-інерційні характеристики людського тіла (включаючи центр ваги) по його індивідуальним антропометричним параметрам на основі 14-сегментної біомеханічної моделі. Представлена блок-схема i описаний відповідний програмний модуль розрахунку, реалізований у середовищі Autodesk Inventor, в якому тіло людини, при визначенні його центра ваги, представлено як складний тривимірний об'єкт. Даний об'єкт складається з елементів різної щільності, при цьому дані про щільність складових частин отримані на основі індивідуальних ознак об'єкта проектування шляхом інтерполяції інформації з зовнішніх спеціалізованих баз даних. Проведено порівняльний аналіз визначення координат центра ваги біологічного об'єкта при використанні як існуючих аналітичної та експериментально - аналітичної методик сегментування, так і запропонованої. Показано, що результати, отримані 3 використанням запропонованої вдосконаленої аналітичної методики, реалізованої в САПР, дуже добре корелюються 3 результатами існуючої експериментально-аналітичної методики з відхиленням $3 . . .4 \%$.

Ключові слова: центр ваги, тіло людини, змінна щільністю, тривимірний, метод сегментації

I. Sydorenko, V. Salii, S. Kovban, M. Kuzmych, Hailong Jiang. Human body CAD modeling in the form of a variable density object. High rates of technological progress contribute to the development and improvement of all spheres of human activity, including biomechanical research. The development of new prostheses, orthoses and exoskeletons place increased demands on the determination of the mass-inertial characteristics of the human body. The paper analyzes the existing experimental-analytical and analytical methods for determining the center of gravity of the human body, which are based on the segmentation method. It is shown that the existing analytical methods do not provide complete information about the individual characteristics of the modeled object, when it is implemented using CAD tools, but give only generalized results without taking into account the physical development, health status and other individual characteristics. An improvement of the analysis technique is proposed, which allows increasing the accuracy of determining the mass-inertial characteristics of the human body (including the center of gravity) by its individual anthropometric parameters on the basis of a 14-segment biomechanical model. The article presents a block-diagram and description of the corresponding software module of the calculation, implemented in the Autodesk Inventor environment, in which the human body, when determining its center of gravity, is represented as a complex three-dimension object. This object consists of elements of different densities, while the data on the density of the constituent parts are obtained on the basis of the individual characteristics of the design object by interpolating information from external specialized databases. A comparative analysis of determining the coordinates of the center of gravity of a biological object using both the existing analytical and experimental-analytical segmentation techniques, and the proposed one is carried out. It is shown that the results obtained using the proposed improved analytical technique implemented in CAD, correlate very well with the results of the existing experimental analytical technique with a deviation of $3 \ldots 4 \%$.

Keywords: center of gravity, human body, variable density, three-dimensional, segmentation method
\end{abstract}

\section{Introduction}

Biomechanical analysis of human body movements requires knowledge of geometric and massinertial characteristics (volume, mass, center of mass, moments of inertia) of human body segments. The moments of inertia and centers of gravity of the human body are fundamental body characteristics involved in any study of human motion. These calculations are applicable to various areas of human activity, such as: designing rehabilitation devices aimed at helping the patient to perform a certain

\section{DOI: 10.15276/opu.1.63.2021.11}

(C) 2021 The Authors. This is an open access article under the CC BY license (http://creativecommons.org/licenses/by/4.0/). 
movement, designing prostheses; analysis of the movement of the whole body under microgravity conditions, when the rotation of the human body is easily produced by its own action or external forces [1]; in sports and forensics under the conditions of body acceleration; in the design of air or space transport systems, where the weight of a person is a significant percentage of the weight of the vehicle [2]; in ergonomics, etc.

Along with the analysis of natural movement, it is important to study the joint work of human body segments and orthopedic devices, which are necessary in the design of prostheses and orthoses, since the orthopedic device must have the appropriate geometry and determine the corresponding mass distribution [3].

\section{Analysis of literary data and problem statement}

It is important to note that the main characteristic is the physical and mechanical properties of most biological tissues have anisotropy. That is, their heterogeneous structure with an unambiguous division into muscle and bone tissue, which determines the differences in their physical and mechanical properties. To determine the center of gravity of solids, it is permissible to use the capabilities of existing computer-aided design systems. The use of the same systems for objects of biological nature often gives an incorrect solution. Finding the center of gravity of a biological object using modern computer-aided design systems is a key task. To solve this problem programmatically, an algorithm should be developed based on a certain methodology.

The analysis of methods for determining the center of gravity of the human body showed that at present this is carried out either experimentally, by direct fixation from the human body [4], or analytically [5]. There are also several experimental-analytical methods, which are called the segmentation method. The use of one of the experimental-analytical method, in particular by the National Aeronautics Administration [6], implies that the location of the center of gravity of the human body changes according to the changing positions of individual parts of the body, which have different physical properties (mass, density), as well as different static moments masses [7]. Therefore, based on this model, the position of the center of gravity can be calculated as the center of gravity of a multi-segment system. In this case, the human body conventionally consists of 14 separate segments (Fig. 1, a). On the segmental model, there are 0 - trunk, 1 - head, 2 and 3 - forearms, 4 and 5 - shoulders, 6 and $7-\operatorname{arms}, 8$ and 9 - thighs, 10 and $11-$ legs, 12 and $13-$ feet [8].

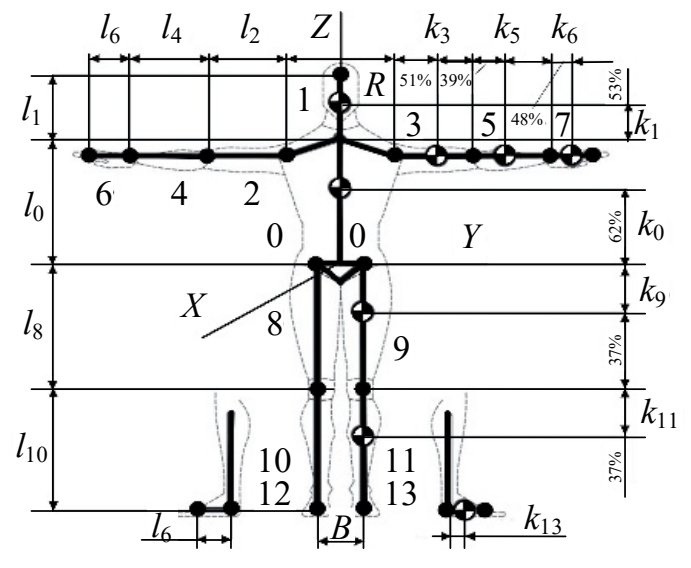

$a$

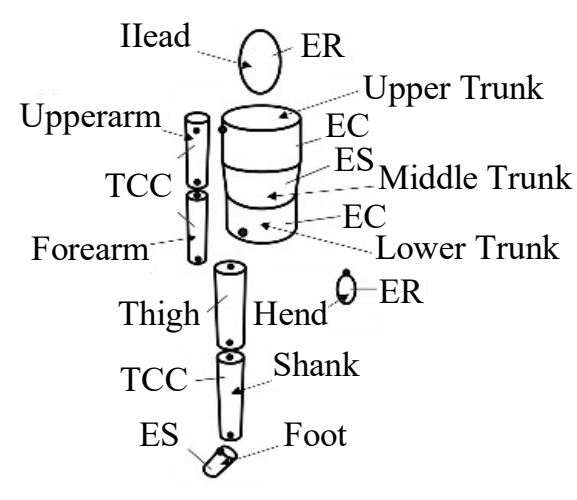

$b$

Fig. 1. Methods for segmentation of the human body in determining its center of gravity: experimental-analytical $(a)$; analytical $(b)$

This segmentation method allows the possibility of replacing each individual segment with an axisymmetric body and requires the designation of the length $l_{i}$, mass and local position of the center of gravity of each of them. Thus, on the axis of symmetry of the $i$-th segment $l_{i}$ at a certain distance $k_{i}$, which is expressed as a percentage, the center of gravity of this segment is located. 
On the basis of measurements, which were carried out on a group of 13 corpses, the data on the location of the centers of gravity and the moments of the segments for the considered experimental analytical method [9] were obtained experimentally.

Subsequent analysis showed that in order to obtain more reliable data, it is necessary to extend the existing segment model with two additional dimensions: the arm span $R$ and the span of the hip joint $B$.

The beginning of the main segment coincides with the beginning of the global reference system $(X 0, Y 0, Z 0)$. Accordingly, other segments of the body's frame of reference begin at the joints connecting them to the previous ones. Hence, we can conclude that the human body in different positions can be projected onto 3 planes of the global reference system $(X 0 Y 0, Z 0 Y 0, X 0 Z 0)$.

This greatly simplifies the process of extracting data from the photograph, in particular the values of the angles of flexion of the joints.

For use in computer-aided design systems, the analytical method is best suited. This method also consists of segmentation of the human body into 14 segments, which are three-dimensional objects of basic geometric shapes or their combination (Fig. 1, $b$ ). In this technique, the arm and head are defined as ellipsoids of rotation (ER), and other body segments are defined as variations of the elliptical body. For example, the truncated cone (TCC) for the forearm, shoulder and lower leg, the elliptical column (EC) for the upper and lower torso, the foot, the cone-shaped elliptical body (ES) for the mid-torso, and elliptical bodies with one round end for the foot and thigh. Using the already known anthropometric parameters of the segment weight as a percentage of the total body weight, the weight of all segments is calculated. In this case, it is assumed that its center of gravity is in the middle of the segment.

It is important to emphasize that the methods described above do not provide complete information about the individual characteristics of the modeled biological individual. They are summarized results without considering physical development, health status or other individual characteristics.

\section{Purpose and tasks of the research}

The purpose of this study is to create an analytical technique that, with increased accuracy, determines the mass-inertial characteristics of the human body (including the center of gravity) by its individual anthropometric parameters based on a 14-segment biomechanical model. As a rule, CAD is now actively used in the development of such biomechanical systems. Even more relevant is the calculation in these environments of the center of gravity of the system under study, as an important indicator affecting its dynamic properties.

To implement this model, CAD - Autodesk Inventor was used. In this case, the segments of the human body are considered as complex three-dimensional objects, which consist of elements of different densities and are formed taking into account the individual characteristics of a person. The 3D model should allow for rapid individualization using parameters obtained directly from a specific research object.

\section{Materials and methods of research}

With the help of a modern diagnostic method - axial $X$-ray densitometry, it is possible to determine the state of bone tissue, fat and fat-free mass of the whole body or its individual segments.

The unified normative database of the National Health and Nutrition Examination Survey III (NHANES III) used in densitometry was adopted as the basis for the creation of specialized databases. The reference base includes data on indicators of bone mineral density according to $T$ - and $Z$-criteria for further comparative analysis. The $T$-score is the number of standard deviations compared to peak bone mass, that is, the mean for the age at which bone mineral density in a given skeletal area reaches its maximum. The $Z$-score is a comparison with the age norm, that is, with the average value for a given age. The comparison result is presented as the standard deviation (SD) of the corresponding norm. According to the recommendations of the World Health Organization, the $T$-test is used for women and men aged 50 and over, and the $Z$-test is used for those under 50 [10,11].

To find the general center of gravity of the human body or its individual parts, taking into account individual characteristics, a software module was created in CAD Autodesk Inventor Professional. This is a further development of the experimental - analytical segmentation technique presented above. The pro- 
posed development of the experimental-analytical segmentation method for determining the center of gravity of the human body in CAD is that all 14 body segments are considered as three-dimensional objects with variable density, i.e. in the form of an "assembly", and not as simplified three-dimensional objects of the main geometric forms of constant density, as it was thought earlier (Fig. 2).

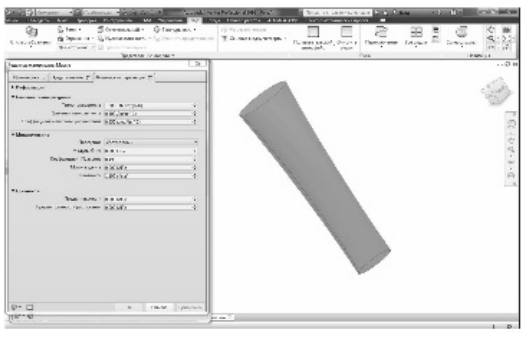

$a$

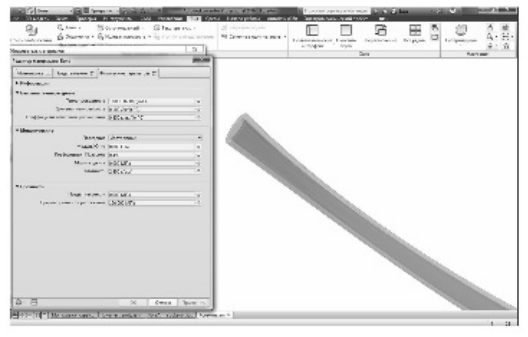

$b$

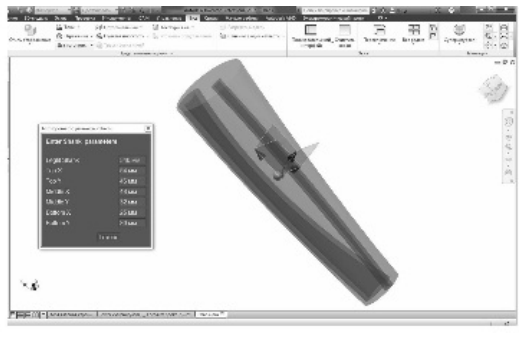

$c$

Fig. 2. Modeling in CAD of segment 3 "forearm" as an object "assembly" with variable density: modeling of muscle tissue $(a)$; modeling bone tissue $(b)$; forearm assembly model $(c)$

Taking into account gender, age, general physical condition and past diseases that affected the state of health, external specialized databases were compiled on the density of bone and muscle tissue ( $\rho_{\text {bone }}$ and $\rho_{\text {muscles }}$ ) of each segment of the human body. They are based on a unified regulatory database used for densitometry of the human body [11]. Accordingly, the proposed method for finding the center of gravity of a person can be announced as analytical, due to the use of certain algorithms for processing these databases and their further use in the CAD environment. The generalized block diagram of the program, drawn up according to this methodology, makes it possible to distinguish the following stages of its work (Fig. 3).

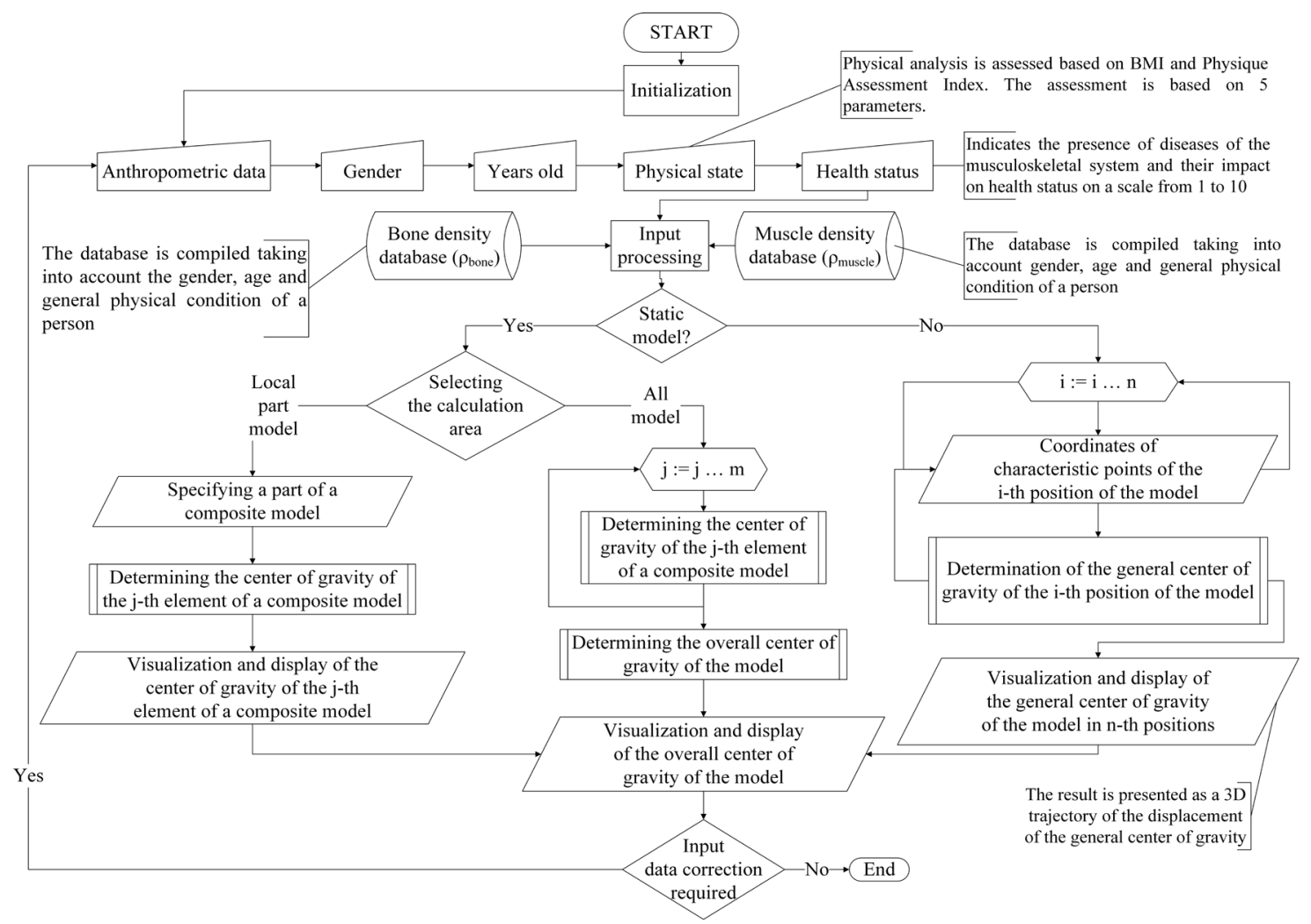

Fig. 3. Block diagram for calculating the center of gravity of a biological object as an assembly with variable density 
The first stage of the program module is the initialization process, the result of which is the assignment of initial values or the zeroing of program variables before executing the program.

Manual input of input data for further operation of the module occurs at the second stage. All data of an individual, telephone modeling are divided into five subgroups: anthropometric data, gender, age, physical condition of a person and his state of health.

Anthropometric data can be obtained either by post-processing a photograph of the research object against the background of a scale grid, or directly by manual measurement and input of this data. These include such parameters of the human body as weight, full height, sitting height, and shoulder girdle width, total length of the limbs and their components, and others.

The physical condition of an individual is assessed (on a scale of 1 to 6) using algorithms for calculating body mass index (BMI) and physique assessment (IOT). The indicator of physical condition, together with the age indicator, makes it possible to determine the density of bone and muscle tissue ( $\rho_{\text {bone }}$ and $\rho_{\text {muscle }}$ ). For a more accurate selection of these indicators, an additional assessment of the state of health is carried out, taking into account the influence of diseases of the musculoskeletal system on the state of health, if any. If the obtained data do not coincide with those available in specialized databases, then this indicator is calculated directly through spline interpolation of the available data.

The third stage consists in shaping the segments of the human body and determining its kinematic structure based on 2D and 3D sketches. The formation of sketches is carried out on the basis of the physical and mechanical properties of the materials of the model obtained as a result of processing the input data. It should be borne in mind that possible modifications of the shapes and positions of the segments, as well as the ways of their interaction with each other, were provided.

The fourth stage of the program is divided into three independent sub-processes and is conditioned by the need to choose a solution option. In the first two sub-processes, static modeling is performed, and the result is output by imposing the desired 3D point on the model.

The first sub-process of this stage determines the local center of gravity of a separate part of the model specified by the user. The second sub-process of the fourth stage is responsible for determining and visualizing the overall center of gravity of the model. In addition to visualizing the resulting $3 \mathrm{D}$ point, the program module also displays its exact coordinates in the global reference system $(X 0, Y 0, Z 0)$.

As indicated above, this system begins at the beginning of the main segment, and for subsequent segments, starting from the joints connecting them with the previous ones. It is important to note that the location of the center of gravity of the model is possible both inside the model and outside it, depending on the position of the body parts relative to each other.

The third sub-process of this stage determines the coordinates of the general center of gravity of the model in motion, with a predetermined range of movement of the segments.

The 3D trajectory of the movement of the general center of gravity of the model in the space of the global reporting system visualizes the result of the work of this part of the software module. At this stage, both the general center of gravity at a certain moment and the local center of gravity of individual segments remain available.

At the final stage of the work of the program module, it is possible to correct the current input data, to reset them completely or to terminate the program.

\section{The discussion of the results}

The analysis of the movement of the human body from the point of view of mechanics should be represented as accurately as possible by a simplified model. In this case, flat, rotational and complex movements were taken into account, as well as the rotational type of movement between segments [4].

Suppose that the fixed point of the segment (at the joints) will be represented by the Cartesian coordinate system $\mathrm{O} X Y Z$. If $P$ is a point of a human body segment and its coordinate is $\left(x^{(1)}, y^{(1)}, z^{(1)}\right)$, then after rotation the coordinate will change to $\left(x^{(2)}, y^{(2)}, z^{(2)}\right)$. Let $P$ rotate the $x, y$ and $z$ axes, respectively, and the corresponding angular displacement will be $\alpha, \beta$ and $\gamma$, then we will have the following kinematic equation: 


$$
\left(\begin{array}{l}
x^{(2)} \\
y^{(2)} \\
z^{(2)}
\end{array}\right)=\left(\begin{array}{ccc}
1 & 0 & 0 \\
0 & \cos \alpha & -\sin \alpha \\
0 & \sin \alpha & \cos \alpha
\end{array}\right)\left(\begin{array}{ccc}
\cos \beta & 0 & \sin \beta \\
0 & 1 & 0 \\
-\sin \beta & 0 & \cos \beta
\end{array}\right)\left(\begin{array}{ccc}
\cos \gamma & -\sin \gamma & 0 \\
\sin \gamma & \cos \gamma & 0 \\
0 & 0 & 1
\end{array}\right)\left(\begin{array}{l}
x^{(1)} \\
y^{(1)} \\
z^{(1)}
\end{array}\right),
$$

which can be simplified:

$$
\left(x^{(2)}, y^{(2)}, z^{(2)}\right)^{T}=\alpha^{(1,2)} \beta^{(1,2)} \gamma^{(1,2)}\left(x^{(1)}, y^{(1)}, z^{(1)}\right)^{T},
$$

where $\alpha^{(1,2)} \beta^{(1,2)} \gamma^{(1,2)}$ are the coefficients of the matrix.

Let the matrix of coefficients of equation (2), in what follows, the transformation matrix of tensor analysis:

$$
S^{(1,2)}=\alpha^{(1,2)} \beta^{(1,2)} \gamma^{(1,2) .}
$$

Let us assume that $\left(e_{1}^{p} e_{2}^{p} e_{3}^{p}\right)$ and $\left(e_{1}^{q} e_{2}^{q} e_{3}^{q}\right)$ for two adjacent segments $B_{p}$ and $B_{q}$ will be concretized, respectively, by unit vectors along the coordinate axes orthogonal to $B_{p}$ and $B_{q}$, then:

$$
S^{(p, q)}=\alpha^{(p, q)} \beta^{(p, q)} \gamma^{(p, q)}=e^{(p)}\left(e^{(q)}\right)^{T} .
$$

Suppose one end of the $B_{q}$ segment is near the other end of the $B_{p}$ segment, and the other end of the $B_{q}$ segment is near the end of the $B_{r}$ segment, and $\left(e_{1}^{r} e_{2}^{r} e_{3}^{r}\right)$ is a unit vector $B_{r}$, instantiated along the coordinate axes. According to formula (3), we obtained:

$$
S^{(p, r)}=\alpha^{(p, r)} \beta^{(p, r)} \gamma^{(p, r)}=e^{(p)}\left(e^{(r)}\right)^{T} .
$$

Then, according to matrix theory:

$$
\left(e^{(r)}\right)^{T}=\left(e^{(q)}\right)^{T} S^{(q, r)} .
$$

Substituting expression (5) into expression (4), we obtained:

$$
S^{(p, r)}=e^{(p)}\left(e^{(q)}\right)^{T} S^{(q, r)}=S^{(p, q)} S^{(q, r)} .
$$

Similarly, using the "chain rule" of the transformation matrix, we obtained:

$$
S^{(0, k)}=S^{(0, p)} S^{(p, q)} \ldots S^{(r, k)}=\prod_{i=0}^{r} S^{(i, i+1)} .
$$

Let $\xi^{(k)}$ be the position vector between the junction point of the body segment and the adjacent segment of the lower ordinal numbers, $r^{(k)}$ be the position vector of the center of mass of the segment relative to the junction point of the segment, then the vector of the position of the center of mass of the segment $B_{k}$ relative to the origin of the grid of the inertial system countdown:

$$
G^{(0, k)}=\sum_{i=1}^{k} S^{(0, i)} \xi^{i}+S^{(0, k)} r^{(k)} .
$$
ment 8):

With regard to a biological object, for example, the vector of the position of the right thigh (seg-

$$
G^{(0,8)}=S^{(0,8)} \xi_{8}+S^{(0,8)} r_{8} .
$$

In the case when $G^{(0, c)}$ determines the position vector of the center of mass relative to the inertial frame of reference, and $m_{k}$ denotes the mass of the segment, according to the theorem of moments, it turns out:

$$
G^{(0, c)}=\frac{1}{\sum m_{k}} \sum G^{(0, k)} \cdot m_{k},
$$

where $\sum G^{(0, k)} \cdot m_{k}$ the resulting moment of all segments relative to the inertial frame of reference 0 .

From expressions (3) and (4) it follows that the main segment parameters of the posture in determining the vector of body position and the position of the center of mass are $r^{(k)}$ and $\xi^{(k)}[12,13]$. Using 


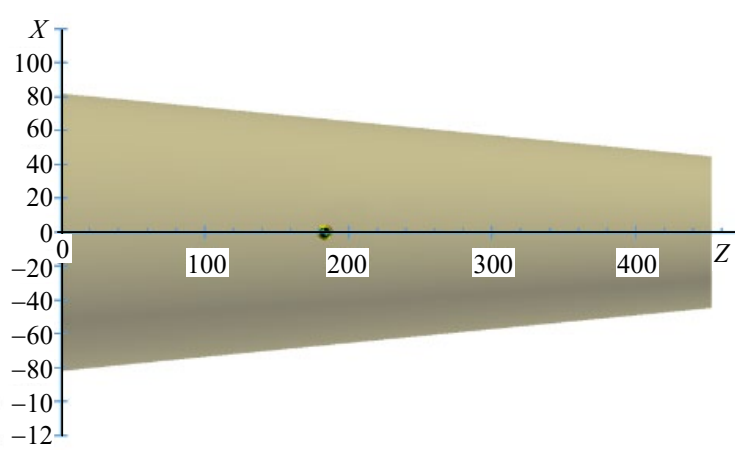

Fig. 4. Visualization of the center of gravity of the thigh determined by the analytical segmentation method expression (4) and the theorem of moments, it is possible to determine the center of mass of the 8th segment of the human body (right thigh) $X=0 \mathrm{~mm}$; $Y=0 \mathrm{~mm} ; Z=202.4 \mathrm{~mm}$, suppose for the case when the height of a person is $1620 \mathrm{~mm}$, and the height of the pelvis is $810 \mathrm{~mm}$.

Determination of the center of gravity of the thigh by the existing method of analytical segmentation implies the representation of a given part of the body in the form of a straight truncated cone with a uniform density $\rho=1.154 \mathrm{~g} / \mathrm{cm}^{3}$. In this case, the center of gravity is located on the axis of symmetry of the body and its coordinates $X=0 \mathrm{~mm} ; Y=0$ $\mathrm{mm} ; Z=190,18 \mathrm{~mm}$ (Fig. 4).

When determining the center of gravity of a biological object according to the proposed method, where it is considered as an object with variable density according to the initial data about an individual, the following was obtained.

According to the given anthropometric data, gender, age, physical condition of a person and his state of health when processing specialized external databases, it was found that the muscle density of the object of the study was $\rho_{\text {muscles }}=1.100 \mathrm{~g} / \mathrm{cm}^{3}$, and the bone tissue density $\rho_{\text {bone }}=2.400 \mathrm{~g} / \mathrm{cm}^{3}$.

Building by means of CAD, according to the given anthropometric parameters, a 3D model of the thigh in four parallel planes made it possible to calculate the coordinates of the desired center of gravity, which for the considered case have the following values $X=2.5 \mathrm{~mm} ; Y=-0.2 \mathrm{~mm} ; Z=170.5 \mathrm{~mm}$ (Fig. 5).

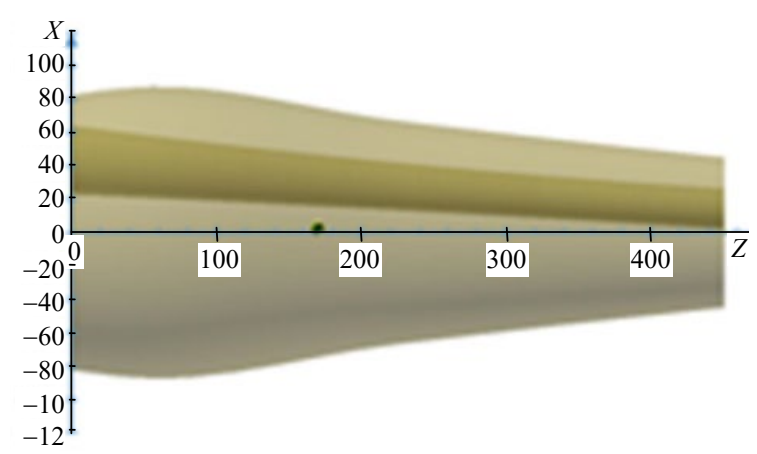

$a$

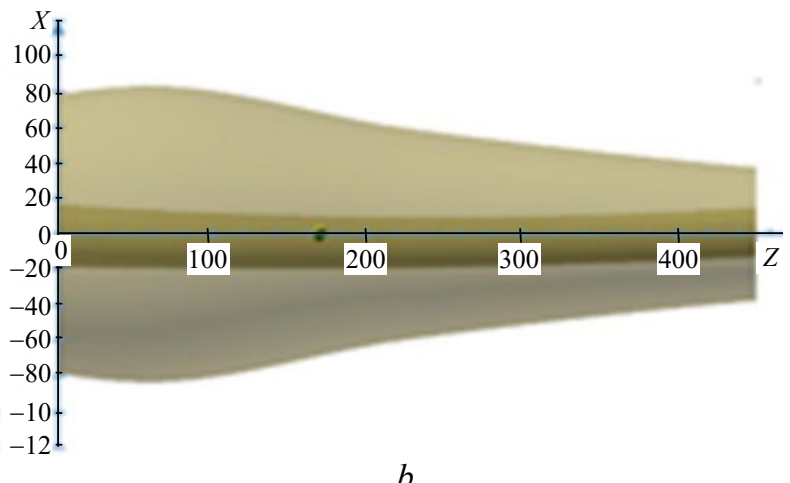

$b$

Fig. 5. Visualization of the center of gravity of the thigh, determined by the proposed segmentation technique in the projection of the $X Z(a)$ and in the projection of the $Y Z(b)$

After analyzing the calculation results, we summarize that the relative position of the center of mass of the considered segment of the human body is equal to $43 \%$ of the length of the thigh from the hip joint when using the existing analytical method; $39.2 \%$ when using the existing experimental analytical technique and $38.89 \%$ - the proposed analytical one, with some deviation of the position of the center of mass relative to the main axes of the adopted frame of reference.

\section{Conclusion}

In the course of the study, it was found that the relative difference between the calculated values of the coordinates of the gravity center of a certain biological object depends on the chosen technique and can reach $15 \ldots 28 \%$. Comparative analysis of the values of the coordinates of the gravity centers of the segments obtained using the improved analytical technique and the existing experimental analytical technique of segmentation showed that they are fairly well correlated with each other. Based on this, it can be argued about a fairly high degree of correspondence of virtual biological objects modeled in CAD to real ones. 
It should be noted that the expansion of specialized databases with information based on the results of medical research will further reduce the error in the results of calculating the coordinates of the mass centers of biological objects as objects with inhomogeneous density.

\section{Література}

1. Макала С., Хатчинсон Дж., Батис К. Кількісна оцінка фізичного та цифрового підходів визначення центру мас. Журнал анатомії . 2017. Том 231 (5). С. 758-775.

2. Котев В.К., Ніколова С., Даніель М.. Визначення масово-інерційних характеристик людського тіла в основних положеннях тіла. Комп'ютерне та математичне моделювання. Доповідь на конферениії у збірнику IFMBE, червень 2018. С. 579-582.

3. Горецький Я.,Кукла М.. Аналітичний метод визначення центру ваги людини, що рухає ручний інвалідний візок. XXI Міжнародна польсько-словацька конференція «Моделювання машин та моделювання 2016». 2017. С. 405-410.

4. Ніколова Г.С., Тошев Ю.С.. Оцінка параметрів чоловічого та жіночого сегментів болгарського населення за допомогою 16-сегментної математичної моделі. Журнал біомеханіки. 2012. Том 45. С. $3700-3707$.

5. Параметричний аналіз конфігурацій удару при ходьбі на милицях / Ф. Холамі та ін.; за ред. Дж. К. Самін, П. Фізетт. Матеріали тематичної конференції ECCOMAS з багатодинамічної динаміки. 2011. C. 1-7.

6. Тесіо Л., Рота В., Перукка Л. 3D-траєкторія руху центру маси тіла під час ходьби дорослої людини: докази закону сили швидкості-кривизни. Журнал біомеханіки. 2011. №44 (4). С. 732-740.

7. Цзінь-Чжуан Сяо, Чжи-Фанг Ян, Хун-Руй Ван. Метод виявлення тривимірного центру тіла людини. Датчики та матеріали. 2017. Вип. 29, №. 7. С. 1081-1087.

8. Ердманн С., Ковальчик Р. Основні інерційні величини багатосегментного тулуба молодих чоловіків, отримані на основі персоніфікованих даних. Журнал біомеханіки. 2020. Том 106. С. 1-6.

9. Чичелла Антоніо. Розвиток біомеханічних технологій для моделювання основних сегментів людського тіла: зв’язок минулого із сучасністю. Біологія. 2020. №9. С. 1-15.

10. Левієкі Майкл, Уоттс Нельсон, Мак Клунг Майкл та ін. Офіційні позиції Міжнародного товариства 3 клінічної денситометрії. Журнал клінічної ендокринології та метаболізму. 2014. Том 89 (8). C. 3651-3655.

11. Радченко В. Денситометрія кісток у клінічній практиці. Ортопедія, травматологія та протезування. 2015. Том 7. С. 88-100.

12. Рота Вівіанаа, Бенедетті Марія Граціак, Окіта Юсукеч. Пластика обертання коліном: рух центру маси тіла під час ходьби. Міжнародний журнал реабілітаџійних досліджень. 2016. Том 39 (4). С. $346-353$.

13. Павей Гаспаре, Семінаті Олена, Каццола Даріо. 3D траєкторією руху центра маси тіла: порівняння між різними методами вимірювання. XXV конференція Міжнародного товариства біомеханіки. Липень 2015. С. 528-529.

\section{References}

1. Macaulay, S., Hutchinson, J. R., \& Bates, K. T. (2017). A quantitative evaluation of physical and digital approaches to centre of mass estimation. Journal of anatomy, 231(5), 758-775.

2. Kotev, V.K., Nikolova, S, \& Daniel, M. (2018). Determination of Mass-Inertial Characteristics of the Human Body in Basic Body Positions: Computer and Mathematical Modelling. Conference Paper in IFMBE proceedings. June 2018. P. 579-582.

3. Gorecki, Jan., \& Kukla, M.. (2017). The Analytical Method of Determining the Center of Gravity of a Person Propelling a Manual Wheelchair. XXI International Polish-Slovak Conference "Machine Modeling and Simulations 2016”. P. 405-410.

4. Nikolova, G.S., \& Toshev, Y.E. (2012). Estimation of male and female body segment parameters of the Bulgarianpopulation using a 16-segmental mathematical model. Journal of Biomechanics, 40, 37003707.

5. Gholami, F. et al. \& Samin, J.C.,. Fisette, P. (Eds.). (2011). Parametric analysis of impact configurations in crutch walking.: Proceedings of the ECCOMAS Thematic Conference on Multibody Dynamics, 1-7.

6. Tesio, L., Rota, V., Perucca, L. (2011). The 3D trajectory of the body centre of mass during adult human walking: Evidence for a speed-curvature power law. Journal of Biomechanics, 44(4), 732-740. 
7. Jin-Zhuang Xiao, Zhi-Fang Yang, \& Hong-Rui Wang. (2017). Detection Method of Human ThreeDimensional Body Center. Sensors and Materials, 29, 7, 1081-1087.

8. Erdmann, S., \& Kowalczyk, R. (2020). Basic inertial quantities including multi-segment trunk of fit, young males obtained based on personalized data. Journal of Biomechanics, 106, 1-6.

9. Cicchella Antonio. (2020). Development of the Biomechanical Technologies for the Modeling of Major Segments of the Human Body: Linking the Past with the Present. Biology, 9, 1-15.

10. E. Michael Lewiecki, \& Nelson B. Watts et al. (2014). Official Positions of the International Society for Clinical Densitometry. The Journal of Clinical Endocrinology \& Metabolism, 89, 8, 3651-3655.

11. Radchenko, V. (2015). Bone densitometry in clinical practice. Orthopaedics, traumatology and prosthetics, 7, 88-100.

12. Rota Vivianaa, Benedetti Maria Graziac, \& Okita Yusukec. (2016). Knee rotationplasty: motion of the body centre of mass during walking. International Journal of Rehabilitation Research, 39 (4), 346-353.

13. Pavei Gaspare, Seminati Elena, \& Cazzola Dario. (2015). 3D Body centre of mass trajectory in locomotion: comparison between different measurements methods. XXV Conference of the International Society of Biomechanics. July 2015. P. 528-529.

Сидоренко Iгор Iванович; Sydorenko Ihor, ORCID: https://orcid.org/0000-0003-1840-4313

Салій Віра Іванівна; Salii Vira, ORCID: https://orcid.org/0000-0003-2426-5241

Кузьмич Максим Володимирович; Kuzmych Maksym, ORCID: https://orcid.org/0000-0002-7658-7851

Ковбан Софія Вікторівна; Kovban Sofiia, ORCID: https://orcid.org/0000-0001-9307-7063

Цзян Хайлун; Jiang Hailong, ORCID: https://orcid.org/ 0000-0003-4738-4163 